\title{
Prevalensi Buta Warna pada Mahasiswa Universitas Muhammadiyah Palembang
}

\section{Prevalence of Color Vision Deficiency in Students of Muhammadiyah Palembang University}

\author{
Mitayani Purwoko \\ Departemen Biologi Kedokteran Fakultas Kedokteran Universitas Muhammadiyah Palembang
}

\begin{abstract}
ABSTRAK
Buta warna adalah ketidakmampuan seseorang untuk membedakan beberapa warna yang dapat dibedakan oleh orang lain. Penyakit ini disebabkan oleh mutasi pada gen OPN1LW, OPN1MW, dan OPN1SW. Keadaan ini diturunkan dengan pola X-linked atau bisa juga didapat setelah lahir. Tujuan penelitian ini adalah untuk menentukan prevalensi buta warna pada mahasiswa Universitas Muhammadiyah Palembang. Penelitian ini merupakan penelitian deskriptif observasional dengan desain potong lintang yang menggunakan data sekunder. Besar sampel sebanyak 174 orang diambil dengan metode stratified random sampling di Fakultas Ekonomi, Fakultas Hukum, dan Fakultas Agama Islam. Mahasiswa yang dipilih adalah mahasiswa angkatan 2017 yang namanya terdaftar di www.forlap.dikti.go.id. Data status penglihatan warna diambil dari arsip skrining buta warna milik Klinik Dokter Keluarga Fakultas Kedokteran UM Palembang. Skrining buta warna dilakukan tim kesehatan penerimaan mahasiswa baru, yang terdiri dari 7 dokter umum, dengan menggunakan Buku Ishihara sebagai alat bantu. Sampel terdiri dari 88 orang laki-laki (50,6\%) dan 86 orang perempuan (49,4\%). Penelitian ini hanya menemukan 1 subjek penelitian dengan buta warna $(0,6 \%)$ berjenis kelamin laki-laki. Angka ini lebih rendah dari angka kejadian nasional yaitu 0,7\% dan angka kejadian di Sumatera Selatan 12,8\%. Hasil penelitian ini sesuai dengan teori bahwa biasanya buta warna terjadi pada laki-laki karena memperoleh kromosom X dari ibu yang membawa alel buta warna. Kesimpulan, prevalensi buta warna pada mahasiswa Universitas Muhammadiyah Palembang tergolong rendah bila dibandingkan prevalensi nasional.
\end{abstract}

Kata Kunci: Buta warna, penyakit herediter, penyakit $X$-linked

\begin{abstract}
Color blind is an inability of a person to distinguish some colors that can be recognized by others. This condition is caused by genetic mutation in OPN1LW, OPN1MW, and OPN1SW gene. This situation is derived with an X-linked pattern or can also be obtained after birth. This study aimed to determine the prevalence of color blindness among students of Muhammadiyah Palembang University. This research was a descriptive observational study with cross sectional design that used secondary data. A sample size of 174 subjects was taken using stratified random sampling at Faculty of Economics and Business, Faculty of Law, and Faculty of Islamic Studies. The selected students were students of 2017 intake whose names were registered at www.forlap.dikti.go.id. Data on color vision status were taken from the archives of color blindness screenings owned by the Family Physician Clinic of Medical Faculty of Muhammadiyah Palembang University. Color blind screening was carried out by Medical Team for new student admission consisting of 7 general practitioners and used Ishihara book as a tool. Research subjects consisted of 88 males (50.6\%) and 86 females (49.4\%). This study only found 1 male subject with color blind (0.6\%). This figure is lower than the national incidence rate of $0.7 \%$, and the incidence rate in South Sumatra is $12.8 \%$. The results of this study are consistent with the theory that color blindness usually occurs in men because of obtaining X chromosome from a mother who carries color-blind allele. In short, the prevalence of color blind in students of Muhammadiyah Palembang University is lower compared to the national prevalence.
\end{abstract}

Keywords: Color blind, color blindness, hereditary disease, $X$-linked disease

Korespondensi: Mitayani Purwoko. Departemen Biologi Kedokteran Fakultas Kedokteran Universitas Muhammadiyah Palembang, Jl. K.H. Balqhi (Talang Banten), 13 Ulu, Palembang 30263 Tel. (0711) 520045 Email:mitayani.dr@gmail.com

DOI: http://dx.doi.org/10.21776/ub.jkb.2018.030.02.15 


\section{PENDAHULUAN}

Buta warna adalah ketidakmampuan seseorang untuk membedakan beberapa warna yang dapat dibedakan oleh orang lain (1). Ketidakmampuan ini disebabkan mutasi pada gen opsin gelombang panjang, gelombang menengah, dan atau gelombang pendek. Gen opsin gelombang panjang (OPN1LW) dan gen opsin gelombang menengah (OPN1MW) terletak pada kromosom Xq28, sedangkan gen opsin gelombang pendek (OPN1SW) terletak pada kromosom 7q32 (2). Penyakit ini biasanya diturunkan secara herediter dari orang tua ke anak dengan pola terkait kromosom $X$ resesif ( $X$-linked recessive). Pola penurunan ini ditunjukkan dengan adanya pewarisan dari seorang ibu kepada anak laki-lakinya sehingga si anak menderita buta warna. Apabila alel diwariskan kepada anak perempuannya, maka anak perempuan tersebut akan menjadi pembawa (carrier) (3).

Buta warna yang diturunkan secara kongenital terdiri dari tiga macam yaitu monokromasi, dikromasi, dan anomali trikromasi. Monokromasi adalah buta warna total, dimana penderitanya tidak dapat membedakan warna akibat kerusakan sel kerucut pada retina. Dikromasi adalah buta warna akibat rusaknya salah satu pigmen sel kerucut sehingga warna hanya dua dimensi. Dikromasi terdiri dari protanopia (tidak ada fotoreseptor warna merah), deuteranopia (tidak ada fotoreseptor warna hijau), dan tritanopia (tidak ada fotoreseptor warna biru). Anomali trikromasi adalah buta warna akibat kerusakan pigmen sel kerucut retina pada bagian sensitivitas spektrum. Anomali trikromasi terdiri dari protanomali dan deuteranomali (sulit membedakan warna merah dan hijau) serta tritanomali (sulit membedakan warna biru dan kuning) (4).

Buta warna secara medis tidak mengancam jiwa. Hal yang menyulitkan dari penyakit ini adalah keterbatasan pemilihan karir di masa depan bagi para penderitanya. Beberapa pekerjaan tidak menolerir buta warna, misalnya dokter. Keahlian klinik seorang dokter dapat terganggu karena adanya buta warna. Hal ini dapat mempengaruhi pengambilan keputusan dalam suatu pengobatan (5).

Angka kejadian buta warna di beberapa negara secara keseluruhan lebih banyak pada laki-laki. Pada ras kaukasia eropa terdapat sekitar $8 \%$ penderita buta warna, ras Chinese sekitar 4\%, dan ras Jepang sekitar 6,5\% (6). Angka kejadian buta warna di Indonesia berdasarkan keluhan penderita adalah $0,7 \%$. Sumatera Selatan termasuk satu dari enam provinsi dengan prevalensi buta warna di atas prevalensi nasional dengan angka 12,8\% (7). Tingginya prevalensi buta warna di Sumatera Selatan perlu mendapat perhatian mengingat penyakit ini dapat diturunkan. Universitas Muhammadiyah Palembang adalah termasuk salah satu universitas besar di Sumatera Selatan, yang menjadi pilihan banyak calon mahasiswa sehingga dapat menjadi lokasi yang representatif untuk skrining buta warna. Penelitian ini dilakukan untuk mengidentifikasi prevalensi buta warna pada mahasiswa UM Palembang sebagai sumbangan data dasar buta warna. Identifikasi dini buta warna pada usia sekolah dan pendidikan tinggi merupakan strategi penting untuk memberikan dasar pilihan pengembangan karir sejak dini.

\section{METODE}

Penelitian ini adalah penelitian deskriptif observasional dengan desain potong lintang yang menggunakan data sekunder. Besar sampel dihitung dengan rumus untuk penelitian potong lintang dan didapatkan 174 subjek penelitian. Subjek penelitian kemudian diambil dengan metode stratified random sampling di Fakultas Ekonomi, Fakultas Hukum, dan Fakultas Agama Islam UM Palembang. Ketiga fakultas ini dipilih karena mahasiswanya tidak harus bebas buta warna sehingga karakteristik mahasiswanya heterogen. Mahasiswa yang dipilih adalah mahasiswa angkatan 2017. Daftar nama mahasiswa diperoleh dari www.forlap.dikti.go.id dan data mengenai status penglihatan warna diperoleh dari arsip rekam medis pemeriksaan calon mahasiswa baru milik Klinik Dokter Keluarga Fakultas Kedokteran UM Palembang. Pemeriksaan status penglihatan warna telah dilakukan oleh Tim Kesehatan yang terdiri dari 7 dokter umum dan 1 dokter spesialis mata pada saat Penerimaan Mahasiswa Baru UM Palembang selama bulan Maret hingga Agustus 2017. Pemeriksaan status penglihatan warna dilakukan dengan cara meminta mahasiswa membaca angka di dalam lempengan warna dalam Buku Ishihara. Uji Ishihara menggunakan pola atau angka pada kartu (plate) dengan seri titik bola kecil dengan warna dan besar yang berbeda (pseudokromatik) (3). Subjek penelitian diminta membaca masing-masing kartu selama maksimal 10 detik. Apabila subjek dapat membaca 10-14 kartu dengan benar, maka dikategorikan tidak buta warna. Apabila subjek hanya mampu membaca kurang dari sama dengan 7 kartu, maka dikategorikan buta warna parsial. Apabila subjek hanya dapat membaca kartu nomor 1 dan tidak mampu membaca semua kartu nomor 2-14 maka dikategorikan buta warna total. Penelitian ini telah mendapatkan sertifikat kelayakan etik penelitian dari Unit Bioetika, Humaniora, dan Kedokteran Islam Fakultas Kedokteran Universitas Muhammadiyah Palembang (No. 001/EC/UBHKI/FK-UMP/IX/2017).

\section{HASIL}

Pemeriksaan tes buta warna dilakukan pada subjek penelitian pada saat tes penerimaan mahasiswa baru di Universitas Muhammadiyah Palembang. Jumlah subjek penelitian laki-laki sebanyak 88 orang $(50,6 \%)$ dan perempuan sebanyak 86 orang $(49,4 \%)$. Distribusi penglihatan warna para subjek penelitian dirangkum dalam tabel 1. Buta warna di dalam penelitian ini dibagi 2 yaitu buta warna parsial (sebagian) dan buta warna total. Pada hasil hanya ditemukan satu subjek dengan buta warna parsial yang berarti subjek tersebut mampu membaca kurang dari sama dengan 7 kartu pada Buku Ishihara. Tabel 1 menggunakan persentase baris dan persentase kolom. Dari tabel 1 dapat terlihat bahwa penderita buta warna dalam penelitian ini adalah laki-laki saja sebanyak 1 orang sehingga bila dilihat berdasarkan jenis kelaminnya maka persentasenya adalah 1,1\% dari seluruh sampel laki-laki. Bila dihitung dari seluruh sampel maka persentasenya adalah $0,6 \%$.

Tabel 1. Distribusi frekuensi status penglihatan warna berdasarkan jenis kelamin

\begin{tabular}{lcrr}
\hline \multirow{2}{*}{ Jenis kelamin } & \multicolumn{2}{c}{ Status penglihatan warna } & \\
\cline { 2 - 3 } & $\begin{array}{c}\text { Buta warna } \\
\text { partial }\end{array}$ & \multicolumn{1}{c}{ Normal } & \\
\hline Laki-laki & $1(1,1 \%)$ & $87(98,7 \%)$ & $88(50,6 \%)$ \\
Perempuan & $0(0,0 \%)$ & $86(100,0 \%)$ & $86(49,4 \%)$ \\
Total & $1(0,6 \%)$ & $173(99,4 \%)$ & $174(100,0 \%)$ \\
\hline
\end{tabular}

Keterangan: ${ }^{*}=$ persentase kolom 


\section{DISKUSI}

Angka kejadian buta warna pada seluruh subjek penelitian ini $(0,6 \%)$ lebih rendah dari angka kejadian buta warna di Indonesia berdasarkan keluhan penderita yaitu sebesar 0,7\% dan angka kejadian di Sumatera Selatan yaitu 12,8\% (7). Angka kejadian buta warna pada seluruh subjek penelitian ini juga lebih rendah dari beberapa populasi di negara lain. Dua penelitian di Iran masing-masing menemukan angka kejadian buta warna pada pegawai laboratorium rumah sakit sebanyak 1,90\% serta angka kejadian buta warna pada siswa sekolah di India sebesar 2,3\% dari 1.561 siswa $(1,8)$. Sebuah penelitian pada penduduk muslim di Manipur, India, mendapatkan angka kejadian buta warna merah-hijau sebanyak 5,28\% dari jumlah sampel (9). Angka kejadian buta warna di Pakistan juga lebih besar yaitu 2,75\% dan 0,9\% $(10,11)$. Hasil survei kesehatan mata pada anak sekolah di Kathmandu, Nepal, melaporkan angka kejadian buta warna kongenital adalah $1,13 \%(12)$.

Penelitian ini memfokuskan diri pada fakultas-fakultas yang tidak mensyaratkan bebas buta warna agar lebih memungkinkan menemukan kejadian buta warna dibandingkan di fakultas-fakultas yang mensyaratkan bebas buta warna. Kondisi ini berbeda dengan satu penelitian di Pakistan yang mengambil sampel mahasiswa kedokteran umum dan kedokteran gigi sebanyak 215 orang, ternyata 12 orang $(5,58 \%)$ di antaranya adalah penderita buta warna (13). Kecilnya kasus yang ditemukan dibandingkan prevalensi pada masyarakat menunjukkan pentingnya dilakukan skrining lebih luas dan dini.

Kasus buta warna pada penelitian ditemukan pada lakilaki. Pewarisan buta warna termasuk penyakit yang diturunkan dengan pola $X$-linked recessive. Hal ini dapat terjadi karena gen OPN1LW dan OPN1MW terletak pada kromosom $X$ yang akan diterima anak laki-laki dari ibunya (14). Hasil penelitian ini berbeda dengan beberapa penelitian di luar negeri yang menemukan wanita dengan buta warna, misalnya hasil pemeriksaan calon karyawan di Pakistan dengan angka kejadian buta warna sebesar $0,9 \%$, dimana $0,4 \%$ adalah laki-laki dan $0,4 \%$ adalah perempuan (12). Penelitian pada berbagai institusi di Pakistan juga memperoleh satu orang perempuan $(0,2 \%)$ yang menderita buta warna (10). Penelitian pada muslim di Manipur, India mendapatkan angka kejadian buta warna pada wanita sebesar $1,69 \%$ (9).

\section{DAFTAR PUSTAKA}

1. Dargahi H, Einollahi N, and Dashti N. Color Blindness Defect and Medical Laboratory Technologists: Unnoticed Problems and the Care for Screening. Acta Medica Iranica. 2010; 48(3): 172-177.

2. Neitz J and Neits M. The Genetics of Normal and Defective Color Vision. Vision Research. 2011; 51(7): 633-651.

3. Kartika, Kuntjoro K, Yenni, dan Halim Y. Patofisiologi dan Diagnosis Buta Warna. Cermin Dunia Kedokteran. 2014; 41(4): 268-271.

4. Darmono. Toksikologi Genetik: Pengaruh, Penyebab dan Akibat Terjadinya Penyakit Gangguan Keturunan. Jakarta: Universitas Indonesia Press; 2012; hal. 127-130.

5. Pramanik T, Sherpa MT, and Shrestha R. Color Vision
Meskipun secara teori buta warna adalah penyakit yang diturunkan secara $X$-linked recessive yaitu laki-laki adalah penderita dan wanita hanyalah pembawa (carrier) namun ada yang dinamakan buta warna didapat yaitu buta warna pada wanita. Dalam buta warna terdapat 1 gen (OPN1SW) yang terletak di kromosom 7 sehingga ada kemungkinan pada perempuan penderita buta warna ini memperoleh kelainan pada gen OPN1SW di kromosom 7, yang pola penurunannya tidak dalam pola $X$-linked. Buta warna didapat juga bisa disebabkan oleh kelainan pada mata, saraf, atau otak akibat paparan zat kimia (4). Salah satu paparan zat kimia yang dapat menimbulkan buta warna adalah obat Etambutol yang merupakan obat untuk penyakit tuberkulosis paru. Satu orang pasien dengan pengobatan tuberkulosis paru di Unit Pengobatan Penyakit Paru-Paru (UP4) Pontianak mengalami buta warna setelah mengonsumsi Etambutol kurang dari 2 bulan dan satu orang mengalami buta warna setelah mengonsumsi Etambutol lebih dari 2 bulan (15). Penelitian ini tidak memperhitungkan faktor penyebab timbulnya buta warna, apakah herediter atau buta warna dapatan. $\mathrm{Hal}$ ini menjadi kelemahan penelitian ini sehingga untuk penelitian selanjutnya sebaiknya perlu melakukan anamnesis pada penderita serta melakukan pemeriksaan buta warna pada keluarga penderita sebanyak tiga generasi untuk menentukan herediter atau tidak.

Penelitian ini mengidentifikasi angka kejadian buta warna yang lebih rendah dibandingkan angka kejadian nasional dan beberapa penelitian di luar negeri, namun harus diwaspadai kemungkinan fenomena gunung es karena lemahnya deteksi dini. Kondisi buta warna tidak hanya mempengaruhi prestasi belajar penderita tetapi juga kepuasan orang tua (16). Oleh karena itu, pemeriksaan kondisi penglihatan warna seseorang sebaiknya dilakukan pada murid sekolah dasar atau sekolah menengah pertama karena hal ini dapat mempengaruhi prestasi belajar, jalur pendidikan dan pengembangan karir.

\section{UCAPAN TERIMA KASIH}

Ucapan terima kasih penulis sampaikan kepada pimpinan Fakultas Kedokteran Universitas Muhammadiyah Palembang atas ijin pengambilan data serta staf Klinik Dokter Keluarga Fakultas Kedokteran Universitas Muhammadiyah Palembang atas bantuan rekapitulasi data.

Deficiency among Medical Students: An Unnoticed Problem. Nepal Medical College Journal. 2010; 12(2): 81-83.

6. Birch J. Worldwide Prevalence of Red-Green Color Deficiency. Journal of the Optical Society of America. A, Optics, Image Science, and Vision. 2012; 29(3): 313-320.

7. Badan Penelitian dan Pengembangan Kesehatan Departemen Kesehatan Republik Indonesia. Riset Kesehatan Dasar 2007. Jakarta: Departemen Kesehatan. 2008; hal. 118.

8. Gupta M, Gupta BP, Chauhan A, and Bhardwaj A. Ocular Morbidity Prevalence Among School Children in Shimla, Himachal, North India. Indian Journal of Ophthalmology. 2009; 57(2): 133-138.

9. Shah A, Hussain R, Fareed M, and Afzal M. Prevalence 
of Red-green Color Vision Defects Among Muslim Males and Females of Manipur, India. Iranian Journal of Public Health. 2013; 42(1): 16-24.

10. Siddiqui QA, Shaikh SA, Qureshi TZ, and Subhan MM. A Comparison of Red-green Color Vision Deficiency Between Medical and Non-medical Students in Pakistan. Saudi Medical Journal. 2010; 31(8): 895899.

11. Chhipa SA, Hashmi FK, Ali S, Kamal M, and Ahmad K. Frequency of Color Blindness in Pre-employment Screening in a Tertiary Health Care Center in Pakistan. Pakistan Journal of Medical Sciences. 2017; 33(2): 430-432.

12. Shrestha RK, Joshi MR, Ghising R, and Rizyal A. Ocular Morbidity among Children Attending Government and Private Schools of Kathmandu Valley. Journal of Nepal Medical Associaiton. 2011;51(184):182-188.
13. Pramanik T, Khatiwa B, and Pandit R. Color Vision Deficiency Among A Group of Students of Health Sciences. Nepal Medical College Journal. 2012; 14(4): 334-336.

14. Mundijo T dan Purwoko M. Dominasi Pewarisan Pola Sidik Jari Whorl Dalam Keluarga Karyawan Fakultas Kedokteran Universitas Muhammadiyah Palembang. Jurnal Kedokteran Brawijaya. 2017; 29(4):312-315.

15. Carissa ID, Nansy E, Hariyanto IH, dan Asroruddin M. Kejadian Buta Warna Pada Pasien Tuberkulosis Paru di Unit Pengobatan Penyakit Paru-Paru (UP4) Pontianak. Cermin Dunia Kedokteran. 2017; 44(4): 237-240.

16. Gallo PG, Panza $M$, Lantieri PB, et al. Some Psychological Aspects of Colour Blindness at School: A Field Study in Calabria and Basilicata (Southern Italy). Color Research and Application. 2003; 28(3): 216-220. 